\title{
SVÉVOLE ZÁKONODÁRCE V JUDIKATUŘE ÚSTAVNÍHO SOUDU
}

\author{
JANA KOKEŠOVÁ
}

\begin{abstract}
The lawmaker's arbitrariness according to the rhetoric of constitutional court
Constitutional court abolishes each law which is in conflict with the constitutional order. In some cases, if the court abolishes the law, it simultaneously entitles the adoption of this law as the arbitrariness of the lawmaker and also designates the arbitrariness as the cause of the unconstitutionality. Can we therefore say that each law which was adopted arbitrarily is unconstitutional? And what it really means that the lawmaker was arbitrary? And is it possible to find different types of the arbitrariness or various arbitrary acts of varying intensity? Those are the issues the article is dealing with. The aim of the text is to refine the understanding of the term arbitrariness of the lawmaker. Since the usage of the term arbitrariness is highly subjective, the article is concerned just with the expressions of the Constitutional Court and tries to find out what the Constitutional court means by the term. Therefore the method used in the article is the analysis of judgments of the Constitutional Court on cases of the lawmaker's arbitrariness.
\end{abstract}

Keywords: lawmaker; Constitutional Court; constitutionality; arbitrariness; typology

Klíčová slova: zákonodárce; Ústavní soud; ústavnost; svévole; typologie

DOI: $10.14712 / 23366478.2018 .27$

\section{ÚVOD}

Pojem svévole se zakládá ve výrazech „svá“ a „vůle“. Zákonodárcova1 vůle a jeho schopnost a možnost svobodné deliberace je přitom nutnou součástí zákonodárné pravomoci. Přestože je vlastní vůle zákonodárce nezbytná pro tvorbu zákonů, označuje termín „svévole“ vadné jednání, kterého by se zákonodárce neměl dopouštět. Co je tedy tímto svévolným jednáním, kterému se má zákonodárce vyhýbat?

1 Zákonodárcem míním složku státní moci, nikoliv jednotlivé fyzické osoby, které jsou členy zákonodárného sboru. K ztotožnění pojmu zákonodárce se složkou státní moci viz např. nález Ústavního soudu ze dne 28. 4. 2009, sp. zn. Pl. ÚS 27/09. 
Používání pojmu svévole není v právní vědě ustáleno. ${ }^{2}$ Zda bude nebo nebude určité zákonodárcovo jednání označeno za svévolné, závisí v subjektivním zhodnocení jednání. Zda bude zákonodárcovo jednání ohodnoceno jako svévolné, se tedy odvíjí od otázky, kdo je hodnotitelem. Subjektivnost hodnocení přitom spočívá ve čtyřech aspektech, a to (1) v podobě hodnotových systémů, vzhledem $\mathrm{k}$ nimž je jednání zákonodárce hodnoceno, ${ }^{3}$ (2) v kritériích zastávaných hodnotitelem při aplikaci jednotlivých hodnotových systémů, ${ }^{4}(3)$ v posouzení a př́ipadném zohlednění reálných zákonodárcových možností hodnotitelem ${ }^{5}$ a (4) v pozici, z níž hodnotitel jednání zákonodárce posuzuje. ${ }^{6}$

Vzhledem k subjektivnosti hodnocení toho, co je a co není svévolí, nelze svévoli zákonodárce obecně definovat prostřednictvím popisu konkrétní vady zákonodárství. $\mathrm{S}$ ohledem na jedinečně specifikovaného hodnotitele je však možné zjistit, co svévolí míní ten který hodnotitel. Tedy např́íklad co svévolí zákonodárce míní konkrétní obyvatel určitého státu, konkrétní právní historik... anebo třeba některý soud. Právě proto, že Ústavní $\operatorname{soud}^{7}$ (a) v mnohých nálezech, jimiž zrušoval zákony nebo jednotlivá zákonná ustanovení jakožto neústavní, poukázal na svévoli zákonodárce jako na př́ícinu neústavnosti, ${ }^{8}$ a zároveň proto, že (b) jen Ústavní soud může přezkoumat ústavnost

2 Odborná literatura dává rozličné odpovědi na to, co by mohlo, či nemohlo být považováno za svévoli, avšak uspokojivě jednoznačnou odpověd’ nenabízí. Naopak se zdá, že svévolí mohou různí autoři mínit různé vady zákonodárství. Srov. např. FORST, R. The right to justification. New York: Columbia University Press, 2012, s. 2; KYNCL, L. Zneuživání veřejných výdajů a svévole v právu veřejných výdajů. In: MUNI Law Working Paper Series [online]. 2014, s. 3, 11. Dostupné na: http://workingpapers.law.muni. cz/dokumenty/29628; RADBRUCH, G. O napětí mezi účely práva. Praha: Wolters Kluwer ČR, 2012, s. 118; DICEY, A, V. Introduction to the study of the law of the constitution. Indianapolis: Liberty Fund, 1982, s. 110 atd. Pojem svévole je z angličtiny překládán jako ,arbitrariness“ viz OHEROVÁ, J. a kol. Anglicko - český právnický slovník. 3. vyd. Praha: Linde, 2005, s. 43.

3 Ten, kdo hodnotí zákonodárství a př́ípadně pak použije pojmu svévole zákonodárce, může zákony hodnotit z hlediska spravedlnosti, účelnosti, racionality, morálky, legálnosti, srozumitelnosti, jasnosti, odůvodněnosti aplikace odlišných př́stupů $\mathrm{k}$ úpravě různých společenských vztahů, popřípadě z hlediska legitimnosti či funkčnosti rozhodovacího procesu při tvorbě zákonů atd. Volba konkrétního hodnotového systému, na jehož základě zákonodárství posouzeno, závisí na subjektivním úsudku hodnotitele. KOKEŠOVÁ, J. Svévole zákonodárce. In: SCHELLE, K. - TAUCHEN, J. Encyklopedie českých právních dějin. Plzeň: Aleš Čeněk (v tisku).

4 Zda konkrétní hodnotitel bude považovat zákonodárce za svévolného nebo nikoliv, bude záviset i na tom, jak si v rámci konkrétního hodnotového systému nastaví kritéria hodnocení. Tedy např́ílad, jestliže bude hodnotovým systémem morálka, záleží na tom, jaká kritéria morálky hodnotitel zastává, tedy jak vnímá standard, který by měl zákon z hlediska morálky naplňovat. KOKEŠOVÁ, J. Svévole zákonodárce, c. d.

5 Totožný hodnotitel totiž může, ,jednoho zákonodárce za svévolného považovat a druhého nikoliv, přestože se oba zákonodárci dopustili stejné chyby“ (KOKEŠOVÁ, J. Svévole zákonodárce, c. d.). To z důvodu zohlednění situací, v nichž se jednotliví zákonodárci při přijímání právních aktů nacházeli a vzhledem $\mathrm{k}$ jejich reálným možnostem, které při přijímání právního aktu měli.

6 Hodnotitel může konkrétní právní akt hodnotit vzhledem k různým standardům zákonodárství. Např́íklad vhledem $\mathrm{k}$ ostatním právním aktům uzákoněným $\mathrm{v}$ dané společnosti, anebo vzhledem ke standardům právních aktů přítomných $\mathrm{v}$ jiné společnosti. Takto bychom například vzhledem ke standardům dnešní západní společnosti mohli hodnotit jako svévolné téměř všechny středověké zákonodárce, avšak vzhledem ke standardům středověké společnosti bychom jistě mnohé za svévolné nepovažovali. KOKEŠOVÁ, J. Svévole zákonodárce, c. d.

7 Ústavním soudem míním zde i po zbytek práce právě Ústavní soud České republiky.

8 Abych prozkoumala, co pod pojmem svévole míní Ústavní soud, vycházím ve výzkumu především z jeho rozhodnutí. Zdrojem těchto primárních pramenů mi byla databáze Beck-online (Beck-online [právní informační systém] C. H. Beck. Dostupné z: https://www.beck-online.cz/), z jejíž sbírky nálezů jsem prošla všechny ty (celkem cca 80 nálezů), které obsahovaly nějaký tvar slova svévole, přičemž se tato svévole 
zákonů, a tak výrazně zasahovat do moci zákonodárné, je důležitou otázkou, co právě Ústavní soud označuje za svévoli zákonodárce. Následující text si proto klade za cíl zpřesnit porozumění pojmu svévole zákonodárce $\mathrm{v}$ tom smyslu, $\mathrm{v}$ jakém je používán Ústavním soudem. Není zde mou ambicí formulovat a předložit vlastní definici svévole ani neusiluji o její komplexní popis. Zkoumám, co je možné se o svévoli dozvědět př́mo z nálezů Ústavního soudu. Jinak řečeno, vycházím z informací, které o svévoli výslovně uvedl Ústavní soud, a ty rozvíjím prostřednictvím analýz nálezů a implicitních poznatků z nich získaných. Svévole zákonodárce je rozsáhlým, důležitým, ale dosud nezpracovaným tématem. Snažím se proto o první kroky k jejímu teoretickému uchopení.

Metodologicky se obracím k tradici analytické filozofie. Ta studuje základní struktury, to, co je, přičemž spatřuje svět jako „zprostředkovaný jazykem“, 9 a právě analýza jazyka tvoří její ústřední zájem. ${ }^{10}$ Analytickou filozofíi se inspiruji a zkoumám používání jazyka, a to takové používání jazyka, které uplatňuje Ústavní soud. Analyzuji proto právě jen ty nálezy Ústavního soudu, $\mathrm{v}$ nichž soud použil ${ }^{11}$ pojem svévole v souvislosti se zákonodárcem. Neptám se, zda pojmu svévole bylo užito úmyslně, nebo naopak jen intuitivně, nýbrž zkoumám př́pady, kdy a jak byl pojem uplatněn. Ani se neptám, zda je vhodné či nevhodné, aby Ústavní soud vůbec zákonodárce za svévolného označoval. Vycházím z faktu, že Ústavní soud pojem svévole zákonodárce použíá, a zkoumám, jak ho použivá. Stejně tak si nepokládám otázku, zda by mohlo být svévolí i některé jiné jednání zákonodárce, zabývám se totiž jen analýzou skutečného užití. Nechci zde ani kriticky hodnotit činnost zákonodárce nebo činnost Ústavního soudu, nepolemizuji s jejich závěry a nezabývám se kvalitou soudní argumentace při rušení zákonů. Soustředím se právě jen na analýzu vyjadřování Ústavního soudu ve věci pojmu svévole zákonodárce.

\section{SVÉVOLE NEROVNÁ SE NEÚSTAVNOST}

Ačkoliv Ústavní soud poukazuje na svévoli zákonodárce při přijímání zákona jako na prríčinu neústavnosti, nelze říci, že neústavnost vzniká automaticky a okamžitě. Neboli nelze říci, že neústavnost zákona nebo jeho části vzniká automaticky a okamžitě po jeho svévolném přijetí. K tomuto tvrzení mě vedou dvě analýzy nálezů Ústavního soudu. Z prvního rozboru lze odvodit, že v některých př́padech závisí na intenzitě zákonodárcovy svévole, zda bude právní akt shledán neústavním. Tedy že nikoliv všechny právní akty, které jsou podle Ústavního soudu svévolně přijaty, budou shledány neústavními. Ve druhé analýze pak rozebírám okamžik, v němž byl zákonodárce svévolný, a porovnávám ho s okamžikem vzniku neústavnosti právního aktu.

vztahovala k činnosti zákonodárce. Šlo o výzkum $\mathrm{k}$ mé diplomové práci a předkládaný článek je právě přepracovaným textem z části této diplomové práce srov. KOKEŠOVÁ, J. Právni akty svévolného zákonodárce. Diplomová práce. Brno 2016, $46 \mathrm{~s}$.

9 PEREGRIN, J. Logika ve filosofii, filosofie v logice: Historický úvod do analytické filosofie. Praha: Herrmann a synové, 1992, s. 9.

10 PEREGRIN, J. Obrat k jazyku: druhé kolo (postanalytická filozofie USA). Praha: Filosofia, 1998, s. 7.

11 Jde tedy o všechny př́ípady výskytu pojmu svévole zákonodárce v nálezech Ústavního soudu, a to včetně těch př́ípadů, kdy se Ústavní soud o svévoli zákonodárce pouze zmínil, aniž by ji třeba v daném př́ípadě shledal. 
Rozbor mě vede k závěru, že neústavnost může vznikat mnohem později, než došlo ke svévoli zákonodárce. $Z$ toho vyplývá, (a) že i svévolně prijjatý právní akt mohl být po určitou dobu ústavně konformní a (b) neústavním se takový právní akt mohl stát až v důsledku přistoupení dalších okolností, nebot' ve světle jejich působení se škodlivé následky svévolně př̌ijatého právního aktu staly intenzivnějšími.

První rozbor se týká nálezu ve věci regulačních poplatků ve zdravotnictví: ${ }^{12}$

\section{P̌̌IIPAD REGULAČNÍCH POPLATKU゚ (PL. ÚS 1/08)}

Ve svém nálezu Ústavní soud uvádí, že v př́ípadě zákonné úpravy sociálních práv (což je i př́ípad úpravy regulačních poplatků ve zdravotnictví) má zákonodárce široký prostor k úvaze. Zásah Ústavního soudu v těchto věcech by mohl přicházet do úvahy toliko, jestliže je svévole zákonodárce „flagrantní“. ${ }^{13}$ Tvrzení o širokém zákonodárcově prostoru k úvaze je založeno na čl. 41 odst. 1 Listiny základních práv a svobod, podle kterého je možné se sociálních práv domáhat pouze v mezích zákonů, které tato ustanovení uvádějí. Sociální práva tak nemusí být naplňována absolutně, a to především z důvodu vysokých požadavků na státní rozpočet, které s sebou sociální práva nesou.

Míra uplatňování sociálních práv je tak z velké míry závislá na hospodářských poměrech státu, ale rovněž na aktuálním politickém směřování země. Ústavní soud je proto při přezkumu zákonné úpravy sociálních práv zdrženlivý. To se vyznačuje mimo jiné i tím, že při přezkumu neaplikuje přísný test proporcionality, ${ }^{14}$ nýbrž pouze mírnější test rozumnosti. ${ }^{15} \mathrm{Na}$ základě testu rozumnosti je shledána jako neústavní jen taková právní úprava, která vykazuje extrémní disproporcionalitu, ${ }^{16}$ neboli kdy je zasaženo „esenciální jádro sociálního práva“. ${ }^{17} \mathrm{~V}$ případě sociálních práv tedy postačuje, aby zákonodárce přijal rozumné řešení situace. Nemusí jím nutně být to nejlepší možné řešení. V nálezu ve věci regulačních poplatků Ústavní soud uvedl, že při aplikaci testu rozumnosti bude shledán neústavním jen takový právní akt, při jehož přijetí se zákonodárce dopustil „flagrantní“ svévole. Z toho vyplývá, že nikoliv každý právní akt, který Ústavní soud považuje za svévolně přijatý, je neústavním. Ústavní soud tak rozlišuje více stupňů intenzity svévole. Alespoň pro některé oblasti právní úpravy (pro ty, kde uplatňuje test racionality) určitou intenzitu svévole toleruje.

Druhý rozbor se věnuje paradoxní situaci dané vyjadřováním soudu o okamžiku svévole zákonodárce a okamžiku vzniku neústavnosti právního aktu. Při rušení svévolně přijatých právních aktů Ústavní soud odůvodňuje své nálezy právě svévolí zákonodárce,

12 Regulační poplatky byly uzákoněny zákonem č. 261/2007 Sb., o stabilizaci veřejných rozpočtů; k tomu nález Ústavního soudu ze dne 20. 5. 2008, sp. zn. Pl. ÚS 1/08. Ústavní soud návrh na zrušení části zákona o stabilizaci veřejných rozpočtu zamítnul, nicméně ve svém nálezu se vyjádřil k pojmu svévole zákonodárce.

13 Nález Ústavního soudu ze dne 20. 5. 2008, sp. zn. Pl. ÚS 1/08.

14 Test proporcionality viz KOSAR̆, D. a kol. Ústavni právo: casebook. Praha: Wolters Kluwer, 2014, s. 362.

15 Test racionality viz KOSA

16 ONDŘEJEK, P. Princip proporcionality a jeho role při interpretaci základnich práv a svobod. 1. vyd. Praha: Leges, 2012, s. 163.

17 WINTR, J. První trri dny nemoci bez nemocenského a ústavní přezkum zákonné úpravy sociálních práv. Jurisprudence, 2008, č. 5, s. 38. 
když použivá výrazy jako „zásah zákonodárce vykazuje znaky svévole“, 18 „postup zákonodárce byl svévolný“ “ ${ }^{19}$ jde o „svévoli státu“20 či zákonné ustanovení ,je výrazem svévole zákonodárce“. ${ }^{21}$ Ústavní soud tak poukazuje na svévoli zákonodárce jako na prríčinu neústavnosti. Otázkou ale je, zda toto zdůvodnění můžeme chápat tak, že neústavnost vzniká jako př́mý následek svévole zákonodárce. Neboli zda neústavnost takového právního aktu vzniká jen a právě na základě svévole. Pokud by sama pouhá svévole zakládala neústavnost, pak by se svévolně prrijatý právní akt musel stát neústavním ihned poté, co byl přijat, nebot' by ke vzniku neústavnosti nepotřeboval žádné jiné okolnosti. Jestliže by neústavnost vznikla $\mathrm{v}$ okamžiku prijjetí právního aktu, pak by takový právní akt měl být zrušen s účinky ex tunc ke dni jeho přijetí, tedy ke dni, kdy se zákonodárce zachoval svévolně. Ovšem praxí Ústavního soudu je rušit zákony, včetně těch svévolně přijatých, s účinky ex nunc ke dni vyhlášení zrušujícího nálezu nebo ke dni pozdějšímu. ${ }^{22}$ Nastává tak paradoxní situace, kdy Ústavní soud vztahuje důvod neústavnosti k okamžiku svévole zákonodárce, tedy jako by neústavnost vznikala právě při prijímání právního aktu. Na druhé straně ale Ústavní soud neruší svévolně přijaté právní akty s účinky k okamžiku, kdy se svévole odehrála, jako by neústavnost vznikala až později. Jistě je řada důvodů, které hovoří pro vhodnost rušení právních předpisů s účinky ex nunc, především jím je právní jistota adresátů práva. Ovšem nelze popř́t, že tím vzniká paradoxní situace. Jak ji vysvětlit? Ilustrujme si věc na př́padu nálezu Ústavního soudu ve věci popírání otcovství:23

\section{P̌̌IIPAD POPŘENÍ OTCOVSTVÍ (PL. ÚS 15/09)}

V zákonu o rodině z roku 1963 zákonodárce zakotvil ustanovením § 57 odst. 1 možnost popření otcovství. Manžel matky, jíž se narodilo dítě, mohl podat popěrnou žalobu „do šesti měsíců ode dne, kdy se dozví, že se dítě narodilo“. 24 V roce 2010 Ústavní soud zmíněné ustanovení zrušil pro neústavnost. Dle argumentace Ústavního soudu neobstojí konstrukce lhůty z hlediska ústavně zaručených základních práv manžela, která jsou zakotvená v čl. 10 odst. 2 a 36 odst. 1 Listiny základních práv a svobod. Těmi je chráněn soukromý a rodinný život a právo na soudní ochranu. Lhůta podle Ústavního soudu také nepřiměřeně omezuje práva dítěte znát své biologické rodiče, uvedená v čl. 7 odst. 1 Úmluvy o právech dítěte. ${ }^{25}$ Ústavní soud považuje stanovení takové lhůty za svévolný zásah státu ${ }^{26}$ do práv jednotlivců. ${ }^{27}$

18 Nález Ústavního soudu ze dne 9. 3. 2004, sp. zn. Pl. ÚS 2/02.

19 Nález Ústavního soudu ze dne 15. 5. 2012, sp. zn. Pl. ÚS 23/09.

20 Nález Ústavního soudu ze dne 22. 9. 1999, sp. zn. II. ÚS 422/97.

21 Nález Ústavního soudu ze dne 14. 7. 2005, sp. zn. Pl. ÚS 34/04.

22 Srov. ŠIMÍČEK, V. Odklad vykonatelnosti nálezů UUstavního soudu v řízení o kontrole norem. Právník. 2002, č. 7, s. 756; KNAPP, V. Zákonodárná moc Ústavního soudu. Právnik. 1992, č. 2, s. 103.

${ }^{23}$ Nález Ústavního soudu ze dne 8. 7. 2010, sp. zn. Pl. ÚS 15/09; zákon č. 94/1963 Sb., o rodině.

24 Ustanovení $§ 57$ odst. 1 zákona č. 94/1963 Sb., o rodině.

25 Úmluva o právech dítěte publikována ve Sbírce zákonu jako Sdělení Federálního ministerstva zahraničních věcí pod č́slem 104/1991 Sb. ve znění zákon č. 129/2008 Sb.

26 Zákonodárcem není míněn jeden člen zákonodárného sboru, nýbrž je jím právě složka státní moci. Zákonodárce tak zde lze ztotožnit se státem. Viz např. nález Ústavního soudu ze dne 28. 4. 2009, sp. zn. Pl. ÚS 27/09; FAIRLIE, J. The Separation of Powers. Michigan Law Review, 1923, roč. 21, č. 4, s. 413.

27 Nález Ústavního soudu ze dne 8. 7. 2010, sp. zn. Pl. ÚS 15/09. 
Ústavní soud tak poukázal na svévoli zákonodárce jako na příčinu neústavnosti. Avšak soud nezkoumal, zda právní úprava byla neústavní v době jejího přijetí, nýbrž se zabývá jen otázkou, zda je neústavní v době přezkumu. Právní úpravu nezkoumal ve světle dokumentů platných a účinných v 60 . letech, nýbrž ve světle Listiny základních svobod a Úmluvy o právech dítěte, které byly přijaty/implementovány do právního řádu České republiky až mnohem později. Ústavní soud tedy ani nezjišt'oval, zda byla nebo nebyla právní úprava popírání otcovství neústavní od samého počátku. Proto ji ani nemohl zrušit s účinky ex tunc. Je tak možné, že právní úprava byla $\mathrm{v}$ době svého přijetí ústavně konformní a až později, působením dalších okolností, se stala neústavní. To sice nemusí být případ veškerých svévolně přijatých právních aktů, nicméně je to pravděpodobné právě ve zmíněné úpravě popírání otcovství.

V roce 1963, kdy byl zákon o rodině príjat, existovaly pouze paternitní testy schopné vyloučit jako otce jen $40 \%$ mužské populace. ${ }^{28}$ Potvrdit otcovství konkrétního muže pak tyto testy nedokázaly vůbec. Biologické vazby mezi dítětem a otcem proto byly pozitivně neprokazatelné. Zákonodárce v roce 1963 poskytl širší ochranu vazbám sociálním na úkor biologických. Ochrana vazby biologické totiž může být v rozporu s ochranou vazby sociální a naopak. Zakotvením neomezené popěrné lhůty by sociální vazby nikdy nebyly definitivně určeny, a naopak zakotvením krátké popěrné lhůty nemusí být možné biologické vazby vůbec prosadit. Právní úprava popírání otcovství umožnila manželu matky dítěte popřít své otcovství jen do šesti měsíců. Po uplynutí této doby zákon přestal chránit právo na zohlednění biologické ne/vazby mezi mužem a dítětem a od toho okamžiku už byly chráněny vazby sociální. Jejich ochrana spočívala v nemožnosti je anulovat popřením otcovství. Zákonodárce tak dal v roce 1963 zakotvením krátké popěrné lhůty větší prostor ochraně vazeb sociálních. To mohl být v době, kdy neexistovaly spolehlivé paternitní testy, a tedy ani spolehlivé určení biologických vazeb, racionální a odůvodnitelný krok. Právní úprava popírání otcovství tak nemusela být v roce 1963 neústavní. Neústavní se mohla stát až později.

Výše jsem nastínila paradoxní situaci, kdy Ústavní soud vztahuje důvod neústavnosti k okamžiku svévole zákonodárce, tedy jako by neústavnost vznikala právě při přijímání právního aktu. Paradoxem je, že na druhé straně Ústavní soud neruší svévolně přijaté právní akty s účinky k okamžiku, kdy se svévole odehrála, jako by neústavnost vznikala až později. Vyřešení tohoto problému spočívá ve zjištění, že Ústavní soud nezkoumá, a tedy ani neví, zda byl právní akt v době príijetí neústavní, a proto ho ani neruší s účinky ex tunc. Takové řešení otevírá prostor pro úvahy o tom, že neústavnost právního aktu nevzniká okamžitě a automaticky po jeho svévolném přijetí. Neústavním se může stát až časem, kdy přistoupí další okolnosti, v jejichž světle se škodlivé následky svévolné-

28 Později se přesnost zvýšila až na $80 \%$ úspěšnost, nicméně stále bez možnosti pozitivně potvrdit skutečného otce. MILANICH, N. The Birth of Uncertainty: A Social, Cultural and Political History of Paternity Testing. Přednáška, 4. 12. 2015, Barnard College, Center for Historical Research, Dept. Of History, The Ohio State University. Dostupné z: https://www.youtube.com/watch?v=WlxvNIUgfo4; DNA test history [online] DNA Diagnostic center. Dostupné z: http://www.dnacenter.com/science-technology/dna-history-1930. html. Až v roce 1992 byl v České republice poprvé vypracován znalecký posudek o určení otcovství za pomoci analýzy DNA. Tento nový paternitní test dokázal pozitivně určit otce s $99,9 \%$ pravděpodobností. LOUDOVÁ, M. - SIEGLOVÁ, Z. Řešení otázky sporného otcovství na počátku 3. tisíciletí - metodiky analýzy DNA umožňují jednoznačnou odpověd'. Právní rozhledy, 2002, č. 4, s. 198. 
ho zákonodárcova jednání stanou intenzivnějšími. $\mathrm{V}$ př́ípadu popěrné lhůty byl těmito okolnostmi (patrně především) technický pokrok umožňující určení otcovství pomocí testů DNA. Právní úprava, která umožňovala popř́ít otcovství pouze do uplynutí šesti měsíců poté, co se manžel matky dozví o narození dítěte, tak v důsledku nových okolností začala intenzivněji intervenovat do práv jednotlivců. Právní úprava se stala neústavní, protože již nešlo odůvodnit upřednostnění sociálních vazeb na úkor těch biologických způsobem, jakým to bylo možné v době jejího přijetí.

Pojem svévole proto není možné ztotožňovat s pojmem neústavnost, a to ze dvou důvodů. Zaprvé jejím fakt, že nejde o totožnou závadu zákonodárství. Svévolí je způsob jednání zákonodárce a neústavností je vlastnost právních aktů. Zadruhé svévole zákonodárce neimplikuje nutně neústavnost právního aktu. Svévole i neústavnost mají vlastní podmínky a di̊vody vzniku. Podmínkou existence svévole zákonodárce je chybné zákonodárcovo jednání při přijímání právního aktu. Podmínkou vzniku neústavnosti takového právního aktu je pak přistoupení dalších okolností, v jejichž světle se škodlivé následky svévolného zákonodárcova jednání stanou intenzivnějšími.

\section{SVÉVOLE ZÁKONODÁRCE: EXPLICITNÍ VYMEZENÍ}

V několika svých nálezech Ústavní soud explicitně označuje za svévoli některé druhy vad zákonodárné činnosti. V nálezu sp. zn. Pl. ÚS 10/03 takto Ústavní soud svévolí zákonodárce míní ,absenc[i] racionální vazby mezi právní úpravou a sledovaným účelem“. ${ }^{29}$ Podobně chápe svévoli i v nálezu sp. zn. Pl. ÚS 56/05, když uvádí: „[...] racionální zdůvodnitelnosti (zákaz svévole) [...].“30 V judikátu sp. zn. Pl. ÚS 83/06 pak Ústavní soud nabízí trochu jiné vymezení svévole: „Není-li daný normativní prostředek způsobilý sledovaného účelu dosáhnout, jde ze strany zákonodárce o projev svévole [...]."31 Pro účely dalšího výkladu nazvěme vymezení pojmu svévole ve výše uvedených nálezech Ústavního soudu souhrnně jako „explicitní vymezení svévole“. Lze uzavřit, že svévolí zákonodárce je podle Ústavního soudu právě přesně to, co v těchto nálezech soud explicitně za svévoli označil? Chce-li se zákonodárce vyhnout svévolnému jednání, postačí, aby se vyvaroval těchto uvedených pochybení? Nakolik dostatečné vymezení svévole nám tímto Ústavní soud poskytl?

Odpověd' na otázku, zda explicitní vymezení svévole představují definici pojetí svévole Ústavním soudem, je kladná, jestliže v rámci judikatury Ústavního soudu neexistuje žádný případ svévole, který by nebyl podřaditelný pod některé z explicitních vymezení. A naopak, jestliže existuje alespoň jeden př́pad, v němž Ústavní soud použil pojem svévole, prričemž tento př́pad není podřaditelný pod explicitní vymezení, pak

29 Nález Ústavního soudu ze dne 19. 1. 2005, sp. zn. Pl. ÚS 10/03.

30 Nález Ústavního soudu ze dne 27. 3. 2008, sp. zn. P1. ÚS 56/05. Nález Ústavního soudu ze dne 19. 1. 2005, sp. zn. Pl. ÚS 10/03 a ze dne 27. 3. 2008, sp. zn. Pl. ÚS 56/05 označují za použití mírně odlišných vyjádření stejné zákonodárcovo pochybení.

31 Nález Ústavního soudu ze dne 12. 3. 2008, sp. zn. Pl. ÚS Pl. ÚS 83/06. Např́ic judikaturou Ústavního soudu lze vysledovat pouze dva druhy vymezení svévole, které Ústavní soud poskytl. První z nich je zmíněno v nálezech ze dne 19. 1. 2005, sp. zn. Pl. ÚS 10/03 a ze dne 27. 3. 2008, sp. zn. Pl. ÚS 56/05 a druhé je uvedeno např́íklad právě v nálezu ze dne 12. 3. 2008, sp. zn. Pl. ÚS Pl. ÚS 83/06. 
explicitní vymezení nepředstavují vyčerpávající definici. Tedy necharakterizují veškeré možné př́pady svévole, jichž se zákonodárce podle judikatury Ústavního soudu dopouští. K vyřešení otázky subsumovatelnosti je zapotřebí nejprve provést rozbor explicitních vymezení svévole a následně, na základě výsledků rozboru, podřaditelnost zjistit.

V nálezu sp. zn. Pl. ÚS 56/05 Ústavní soud uvedl, že svévolí zákonodárce je absence racionální zdůvodnitelnosti právní úpravy. ${ }^{32} \mathrm{~K}$ tomuto vymezení dospěl v rámci posouzení ústavnosti právní úpravy obchodního zákoníku ve věci nuceného výkupu akcií. ${ }^{33}$

\section{P̌̌IIPAD NUCENÉHO VÝKUPU AKCIÍ (PL. ÚS 56/05)}

V roce 2008 Ústavní soud posuzoval ústavnost několika ustanovení obchodního zákoníku, která umožňovala nucený výkup akcií minoritních akcionár̊u hlavním akcionářem. ${ }^{34}$ Zákonodárce touto právní úpravou realizoval ústavně zaručené právo na podnikání $\mathrm{v}$ rámci akciové společnosti. Zároveň tím nicméně omezil členská práva spoluvlastníků, jejichž akcie mohly být vykoupeny hlavním akcionářem. Právní úprava se zdála být diskriminační vůči minoritním společníkům, a tedy rozporná s ústavně zakotveným požadavkem rovnosti. Stojí zde tak proti sobě právo na podnikání na jedné straně a zásada rovnosti účastníků právních vztahů na straně druhé.

Ústavní soud uvádí, že dotčenou právní úpravu obchodního zákoníku přezkoumal z hlediska „[...] racionální zdůvodnitelnosti (zákaz svévole) $[\ldots . . .]^{6.35}$ A contrario lze říci, že svévolí je racionální nezdůvodnitelnost právní úpravy.

Je tedy zakotvení právní úpravy nuceného výkupu akcií zdůvodnitelné? Z právní věty nálezu Ústavního soudu vyplývá, že dotčená ustanovení obchodního zákoníku nejsou svévolná, nebot' existuje důvod $\mathrm{k}$ upřednostnění práva podnikat před právem minoritních akcionářů na rovnost. Nucený výkup akcií se totiž týká akciové společnosti, jejímž primárním účelem je podnikání a dosahování zisku, nikoliv pouhé sdružování osob. V př́padě akciové společnosti je tedy dán racionální důvod k zakotvení institutu nuceného výkupu akcií. Tímto důvodem je umožnit flexibilnější řízení společnosti, prostřednictvím čehož jsou posíleny možnosti dosahování zisku. Zákonodárce proto při přijímání zákonných ustanovení obchodního zákoníku nebyl svévolný.

Ústavní soud dále uvádí, že jinak by tomu bylo, pokud by zákonodárce zakotvil obdobný institut např́iklad v př́ípadě náboženských nebo odborových organizací. Nucené zbavení členských práv členů těchto organizací by mohlo být svévolné, nebot' by $\mathrm{k}$ takovému postupu vzhledem $\mathrm{k}$ účelu těchto organizací nebyl dán racionální důvod. Neboli nebyl by dán racionální důvod k omezení práv členů těchto organizací. Práva členů by tak byla omezena bezdůvodně, tedy svévolně.

32 Řízení v této věci bylo skončeno zamítnutím návrhu, nicméně přesto v tomto nálezu Ústavní soud poskytl vymezení pojmu svévole. V nálezu ze dne 19. 1. 2005, sp. zn. Pl. ÚS 10/03 Ústavní soud vymezuje svévoli v zásadě stejným způsobem. Viz pozn. č. 4.

33 Ustanovení § 183i až 183n zákona č. 513/1991 Sb., obchodní zákoník.

34 Nález Ústavního soudu ze dne 27. 3. 2008, sp. zn. Pl. ÚS 56/05, v rámci něhož byla posouzena ustanovení § 183i až 183n zákona č. 513/1991 Sb., obchodní zákoník.

35 Nález Ústavního soudu ze dne 27. 3. 2008, sp. zn. Pl. ÚS 56/05. 
Racionální vazba mezi právním prostředkem a sledovaným účelem je dána, pokud existuje rozumný důvod pro přijetí i takové právní úpravy, která omezuje některá práva ostatních členů právních vztahů. $V$ opačném případě se jedná o svévoli zákonodárce. ${ }^{36}$

Ve druhém explicitním vymezení popsal Ústavní soud svévoli zákonodárce jako přijetí takové právní úpravy, která není způsobilá dosáhnout sledovaného účelu. Šlo o nález sp. zn. Pl. ÚS 83/06.

\section{P̌̌IIPAD ZAMĚSTNANECKÝCH RAD (PL. ÚS 83/06)}

Ústavní soud svým nálezem z roku 2008 zrušil některá ustanovení zákoníku práce. ${ }^{37}$ Jedněmi z nich byla ustanovení $\S 278$ odst. $1, \S 281$ odst. 1 a $\S 282$ odst. 1 a 2 , která se týkala vzniku a působení zaměstnaneckých orgánů u zaměstnavatele. ${ }^{38}$

Těmito ustanoveními zákonodárce prováděl do českého právního řádu směrnici práva Evropské unie. ${ }^{39}$ Tato směrnice zákonodárci (mimo jiné) uložila, aby umožnil zaměstnancům rovný výkon jejich práv plynoucích ze zaměstnaneckého poměru.

Zákonodárce na základě směrnice přijal právní úpravu v zákoníku práce, avšak omezil možnost zřízení rad zaměstnanců. Zakázal totiž jejich zřízení u těch zaměstnavatelů, u kterých již působily odborové organizace. ${ }^{40}$ Tím došlo k znemožnění realizace práva zaměstnanců zvolit si orgán, který by je zastupoval. Dále pak, vzhledem k nerovnému postavení zaměstnaneckých orgánů, byli zaměstnanci nuceni $\mathrm{k}$ výkonu některých práv jen prostřednictvím odborových organizací.

Právní úprava, kterou zákonodárce $\mathrm{v}$ zákoníku práce přijal, tak nebyla způsobilá naplnit svůj účel. K tomu Ústavní soud uvádí, že pokud normativní prostředek není způsobilý sledovaného účelu dosáhnout, jde ze strany zákonodárce o projev svévole.

Ústavní soud tedy charakterizoval svévoli na základě vztahu mezi právní úpravou na jedné straně a jejím účelem na straně druhé. Ústavní soud tak explicitně vymezil svévoli jako př́ípad príijetí (a) takové právní úpravy, která nemá racionální vazbu na svůj účel, nebo (b) takové právní úpravy, která není schopna svého účelu dosáhnout. Př́kladem př́padu, který není možné charakterizovat prostřednictvím explicitního vymezení svévole, je kupř́íkladu nález sp. zn. Pl. ÚS 1/12 ve věci neústavního průběhu přijímání zákona. ${ }^{41}$

36 Ačkoliv v případu nuceného výkupu akcií (Pl. ÚS 56/05) Ústavní soud neshledal, že by se zákonodárce dopustil svévole zákonodárce, poskytl nám prostřednictvím nálezu v této věci vymezení pojmu svévole.

37 Nález Ústavního soudu ze dne 12. 3. 2008, sp. zn. Pl. ÚS 83/06.

38 Zákon č. 262/2006 Sb., zákoník práce.

39 Směrnice Evropského parlamentu a Rady č. 2002/14/ES ze dne 11. 3. 2002, viz též nález Ústavního soudu ze dne 12. 3. 2008, sp. zn. Pl. ÚS 83/06.

40 Následkem této úpravy zaměstnanci nemají možnost výběru orgánů, které by je zastupovaly. Jsou tak nuceni akceptovat existující odborové organizace, a pokud nechtějí, aby je daná odborová organizace zastupovala, musí založit jinou odborovou organizaci. Zaměstnancům tak není umožněn výkon jejich práva na informace a projednání. Nález Ústavního soudu ze dne 12. 3. 2008, sp. zn. P1. ÚS 83/06.

41 Nález Ústavního soudu ze dne 27. 11. 2012, sp. zn. Pl. ÚS 1/12. 
V rámci přijímání zákona o zdravotních službách ${ }^{43}$ byla rozhodnutím parlamentní většiny omezena práva poslanců při projednání návrhů. Parlamentní opozice si stěžovala na nesprávný postup při přijímání zákonů, přičemž chybu spatřovala v omezení řečnických dob poslanců a počtu jejich vystoupení. Dále pak byly zkráceny lhủty pro projednání návrhů. Ústavní soud $\mathrm{k}$ tomu uvedl, že taková omezení mohou být za určitých okolností projevem svévole. ${ }^{44}$

Vymezení svévole, které bylo explicitně vyjádřeno Ústavním soudem, nelze vztáhnout na př́ípad údajného neústavního přijímání zákona. I zákon, který byl přijat neústavním způsobem, totiž může být účelný, nemusí bezdůvodně omezovat práva účastníků právních vztahů a může být schopen naplnit cíl, ke kterému byl príijat. Explicitní vymezení svévole tak není vyčerpávající definici veškerých zákonodárcových svévolných jednání.

\section{TYPOLOGIE}

Jestliže explicitní vymezení svévole označují pouze část těch jednání, která Ústavní soud považuje za svévolná, pak o jakou část jde? Jestliže existuje více různých způsobů, kterými se zákonodárce může zachovat svévolně, pak je vhodné tyto způsoby systematizovat, tedy vytvořit typologii svévolných jednání zákonodárce. Navrhuji typologii, která byla vytvořena kombinací př́stupu induktivního a deduktivního. Analyzovala jsem nálezy Ústavního soudu a zároveň v odborné literatuře pro dané př́ípady hledala již existující dělení, umožňující vytvořit přiléhající a funkční typologii.

Jelikož svévolná jednání zákonodárce vykazují značnou rozmanitost, je třeba pro vytvoření účelné typologie nalézt takové kritérium, které bude možné stejně použít jako slučovací i rozlučovací rys. Vycházím z faktu, že svévole zákonodárce může vést k neústavnosti přijatého právního aktu. Právní akt je neústavní, je-li v rozporu nebo v nesouladu s ústavním pořádkem. ${ }^{45}$ Svévolí zákonodárce je proto porušení těch norem, které zákonodárci stanovují, jak přijímat ústavně konformní právní předpisy. Výchozím slučovacím i rozlučovacím rysem pro vytvoření typologie budou právě takové normy. V zásadě jde o normy z patera oblastí: ${ }^{46}$

$42 \mathrm{~V}$ tomto případě Ústavní soud dospěl $\mathrm{k}$ závěru, že způsob přijetí napadených zákonů byl v souladu s Ústavou a že $\mathrm{k}$ přijetí a vydání napadených zákonů došlo v mezích Ústavou stanovené kompetence a ústavně předepsaným způsobem.

43 Zákon č. 372/2011 Sb., o zdravotních službách.

44 Nález Ústavního soudu ze dne 27. 11. 2012, sp. zn. Pl. ÚS 1/12. Ústavní soud v tomto př́padě sice dospěl k závěru, že způsob přijetí napadených zákonů byl v souladu s Ústavou, nicméně prostřednictvím nálezu $\mathrm{v}$ tomto prípadu poskytl obraz toho, co také míní pod pojmem svévole zákonodárce.

45 FILIP, J. Pojem rozporu (nesouladu) zákona s ústavním pořádkem v teorii a judikatuře Ústavního soudu. Časopis pro právní védu a praxi, 2010, č. 2, s. 93-94.

46 Všech těchto pět oblastí vymezil Jan Filip na základě praxe rušení zákonů Ústavním soudem. FILIP, 2010, c. d., s. 94 a násl. 
a) legislativní pravomoc zákonodárce, přičemž legislativní pravomocí je schopnost orgánu veřejné moci tvořit právní normy, tedy oprávnění vydávat určité právní předpisy; ${ }^{47}$

b) kompetence zákonodárce, přičemž kompetenci zákonodárce můžeme chápat jako sféru, v níž mohou právní normy vydané zákonodárcem vyvolávat následky;

c) správnost zákonodárného procesu, přičemž zákonodárný proces je správný, je-li dodržen stanovený postup pro přijímání právního předpisu; ${ }^{48}$

d) řádnost publikace přijatého právního aktu, kam spadá správné označení, vyhlášení a publikaci právního předpisu; 49

e) obsah přijímaného právního aktu, kterým zákonodárce směřuje adresátům práva příkazy, zákazy a povolení (viz obr. 1).

\section{PŘEZKUM ÚSTAVNÍM SOUDEM}

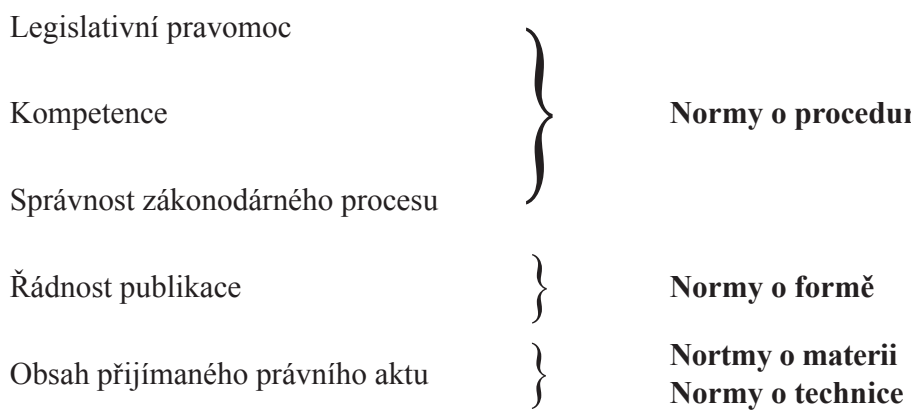

Obrázek 1

Legislativní pravomoc, kompetence a správnost zákonodárného procesu se vážou k procedurám přijímání zákonů. Nazývejme proto skupinu norem, která zahrnuje tyto oblasti, souhrnným názvem normy o procedurách (viz obr. 1).

Normy týkající se řádnosti publikace upravují především formu, $v$ jaké má být přijatý zákon publikován, nazývejme tuto skupinu norem pojmem normy o formě (viz obr. 1).

Poslední skupina norem se týká obsahu přijímaného zákona (viz obr. 1 vlevo). Obsah zákona je Ústavním soudem přezkoumáván v rámci materiální kontroly ústavnosti, jíž je zjištění, zda zákon zahrnuje ustanovení neslučitelná s ústavními normami, přičemž ústavní norma v tomto smyslu nemusí být totožná s konkrétní částí textu právního předpisu, nýbrž její obsah je tvořen působením diverzifikovaných faktorư ${ }^{50}$ včetně hodnot,

47 Srov. ŠÍN, Zbyněk. Právní norma a normativnost práva v evropském legislativním kodexu. Právník, 2008, č. 12 , s. 1370 .

48 Srov. FILIP, 2010, c. d., s. 95.

49 Srov. GERLOCH, A. a kol. Teorie a praxe tvorby práva. Praha: ASPI, 2008, s. 237 a násl.

50 GERLOCH, A. - TRYZNA, J. Několik úvah nad rolí nejvyšších soudů v podmínkách demokratického právního státu. In: ŠIMÍČEK, V. Role nejvyšších soudů v evropských ústavních systémech - čas pro změnu? Brno: Masarykova univerzita, 2007, s. 94. 
principů ${ }^{51}$ a politik..$^{52}$ Normy upravující obsah zákona, tedy materii, označuji jako normy o materii (viz obr. 1).

$\mathrm{Z}$ obsahu zákona můžeme vedle materie zjistit i způsob úpravy této materie neboli techniku úpravy. Pro zjištění, zda se zákonodárce dopustil chyby v této oblasti, je třeba analyzovat použitou terminologii, systematiku výstavby zákona i výstavby právního řádu jako celku. Dále je třeba prověřit srozumitelnost, ${ }^{53}$ určitost, jednoznačnost a jasnost textu zákona. ${ }^{54}$ Zkoumáme tak samotnou konstrukci právního předpisu a zjišt'ujeme, zda právní norma $\mathrm{v}$ něm obsažená skutečně může vyvolávat právní následky. Normy, které ukládají zákonodárci př́íkazy nebo zákazy ${ }^{55}$ ohledně konstrukce zákona, nazývám normy o technice (viz obr. 1).

Máme tak čtyři skupiny norem, a to normy proceduře, formě, materii a technice. Na základě toho, které z těchto skupin norem zákonodárce porušil, rozeznávám čtyři typy svévole, a to svévoli procedurální, formální, materiální a technickou.

Po rozvržení čtyř typů svévole nyní uvádím specifika jednotlivých typů. Jestliže je definován typ svévole procedurální, technické, formální a materiální, pak ta materiální se týká právě obsahu zákona. Nikoliv ale konkrétního doslovného textu, nýbrž smyslu, který zákon nese, tedy jeho materie. Zákonodárce se dopustí materiální svévole, pokud přijme takový právní předpis, který je v rozporu s normami, jež vytyčují materii přijímaného právního předpisu. Pramenem těchto norem je především Ústava a Listina základních práv a svobod. Právě typ materiální svévole odpovídá výše popsaným př́padům, v nichž Ústavní soud explicitně vymezil svévoli. Tedy př́ípadu zaměstnaneckých rad, v němž svévolí bylo přijetí právní úpravy neschopné svého účelu dosáhnout, ${ }^{56}$ a př́padu nuceného výkupu akcií, z něhož bylo dovozeno, že svévolí je přijetí právní úpravy, která nemá racionální vazbu na svůj účel. ${ }^{57}$ Právě v obou těchto př́padech Ústavní soud uváděl svévoli zákonodárce do spojitosti s materií přijatých zákonů. $\mathrm{Z}$ dosavadního výzkumu vyplývá, že právě všechny př́pady materiální svévole zákonodárce lze popsat prostřednictvím některého $\mathrm{z}$ obou explicitních vymezení. Naproti tomu př́pady typu svévole procedurální, technické a formální explicitními vymezeními charakterizovat bud' nelze vůbec popř́padě je výsledek sporný. Právě bezproblémová aplikace explicitního vymezení na jakýkoliv př́pad materiální svévole ukazuje, že explicitním vymezením definoval Ústavní soud právě jen materiální typ svévole.

Procedurální svévole se zákonodárce dopustí, jestliže poruší normy týkající se legislativního procesu. Takové normy nalézáme především v Ústavě a v zákonech o jednacích řádech komor Parlamentu. ${ }^{58}$ Při určení, zda jde o procedurální svévoli, nezkoumáme obsah přijatého zákona, ten může být sám o sobě v naprostém pořádku. Svévole

51 MELZER, F. Metodologie nalézání práva. Úvod do právní argumentace. 2. vyd. Praha: C. H. Beck, 2011, s. 54.

52 DWORKIN, R. Když se práva berou vážně. Praha: Oikoymenh, 2001, s. 44.

53 ŠKOP, M. Jazyková metoda interpretace práva - důvod k nejistotě? In: GERLOCH, A. a kol. Metodologie interpretace práva a právní jistota. Plzeň: Aleš Čeněk, 2012, s. 288.

54 Popř́padě jeho adekvátní interpretovatelnosti. Nález Ústavního soudu ze dne 24. 3. 2009, sp. zn. Pl. ÚS 27/06 a nález Ústavního soudu ze dne 22. 4. 2008, sp. zn. Pl. ÚS 35/06.

55 KRECHT, J. Normy a jiné normativní akty. Právník, 2010, č. 5, s. 502.

56 Nález Ústavního soudu ze dne 12. 3. 2008, sp. zn. Pl. ÚS 83/06.

57 Nález Ústavního soudu ze dne 27. 3. 2008, sp. zn. Pl. ÚS 56/05. Viz kapitola „Svévole zákonodárce“.

58 Zákon č. 90/1995 Sb., o jednacím řádu Poslanecké sněmovny a zákon č. 107/1999 o jednacím řádu Senátu. 
spočívá ve vadném průběhu přijímání zákona. Příkladem tohoto typu svévole je nález sp. zn. Pl. ÚS $1 / 12$ ve věci př́padu neústavního přijímání zákona, popsaného už výše v textu. 59

Technickou svévoli, stejně jako dále svévoli materiální, nalézáme v obsahu zákona. Při objevování technické svévole je však třeba všímat si nikoliv materie či účelu textu, nýbrž jeho organizace nebo způsobu, jakým jsou v něm právní normy vyjádřeny. Technická svévole tak spočívá $\mathrm{v}$ chybě uspořádání textu $\mathrm{v}$ zákoně nebo zákona v právním řádu. Konkrétně může být technickou svévolí vada v odkazování na jiná ustanovení či jiné právní předpisy; používání matoucích výrazů nebo pojmů, které jsou na jiných místech právního řádu uváděny v odlišném smyslu, a také ji lze hledat v uplatnění nesrozumitelných, nejasných nebo nejednoznačných výrazů. Př́ikladem technické svévole je př́pad zákona o půdě, kterým se Ústavní soud zabýval v nálezu sp. zn. Pl. ÚS 71/04.

\section{PĽ́IPAD ZÁKONA O PŮDĚ (PL. ÚS 71/04)}

V ustanovení § 11 odst. 5 zákona o půdě zákonodárce navázal možnost uplatnění restitučního nároku na toho času neexistující zákon, když uvedl: „Nemovitost, která je prohlášena národní kulturní památkou, nelze vydat až do doby přijetí zákonů upravujících správu a ochranu kulturních památek." ${ }^{60}$ Zákon upravující správu a ochranu kulturních památek v době vydání zákona o půdě neexistoval, a oprávněné osoby tak nemohly uplatnit své restituční nároky. Ústavní soud v nálezu $\mathrm{k}$ této věci konstatoval, že svévolí zákonodárce není fakt, že zákonodárce dosud nevydal právní úpravu o správě a ochraně kulturních památek. Svévole zákonodárce spočívala v tom, že navázal možnost uplatnění restitučního nároku na takovou podmínku. ${ }^{61}$

Technická svévole je následkem nedostatečné péče o právní řád, kdy je narušena souladnost systému uspořádání norem. Právní řád je pak vnitřně rozporný, sám sebe vyvrací ${ }^{2}$ či obsahuje legislativní mezery. ${ }^{63}$ Tyto chyby pak mohou vést v konečném důsledku až k nepoužitelnosti některých ustanovení.

Formální svévolí zákonodárce je nedostatek při vyhlašování zákona či vada formálního označení právního aktu. Chyba má za následek nesprávnou právní sílu zákona a nesprávné zasazení do hierarchie právního řádu. ${ }^{64}$ Příkladem formální svévole je nález

59 Viz kapitola „Svévole zákonodárce“.

60 Zákon č. 229/1991 Sb., o úpravě vlastnických vztahů k půdě a jinému zemědělskému majetku (zákon o půdě).

61 Nález Ústavního soudu ze dne 17. 5. 2005, sp. zn. Pl. ÚS 71/04.

62 Srov. souladnost práva a souladnost systému práva. ŠíN, Z. Tvorba práva: pravidla, metodika, technika. 2. vyd. Praha 2003, s. 8.

63 Těmi jsou neregulované oblasti společenských vztahů, ve kterých se ale tvorba pravidel předpokládá z důvodu požadavku konzistence právního řádu. Jde o vymezení mezer v právu dle Clause-Wilhelma Canara. HLOUCH, L. Teorie mezer a současné právní myšlení. Časopis pro právní vědu a praxi, 2013, č. 2, s. 131.

64 Prameny práva mají vlastnost právní sílu, na základě níž jsou hierarchicky uspořádány v právním řádu KNAPP, V. a kol. Tvorba práva a její současné problémy. Praha: Linde, 1998, s. 45. 
sp. zn. Pl ÚS 27/09, kterým Ústavní soud zrušil ústavní zákon o zkrácení pátého volebního období Poslanecké sněmovny. 65

\section{PŘIIPAD NEÚSTAVNÍHO ÚSTAVNÍHO ZÁKONA (PL. ÚS 27/09)}

Před přijetím ústavního zákona o zkrácení volebního období převládalo v Poslanecké sněmovně přesvědčení, že již není možné sestavit většinu, která by dokončila zbývající rok ze čtyřletého volebního období. ${ }^{66}$ Nicméně rozpustit Poslaneckou sněmovnu lze pouze z taxativních důvodů, přičemž žádný z nich se nedal použít pro nastalou situaci. Byl proto přijat ústavní zákon ad hoc o zkrácení volebního období67 a na jeho základě pak mohlo dojít k rozpuštění sněmovny a předčasným volbám. ${ }^{68}$

Ústavní soud ale takto přijatý zákon zrušil a uvedl, že daný zákon je ústavním pouze formou, nikoliv však obsahem. Obsahem je totiž individuálním právním aktem. Zákonodárce tak porušil princip obecnosti zákona, ${ }^{69}$ nebot' se zákon týkal ,nikoliv obecně vymezeného okruhu adresátů a situací, nýbrž konkrétně určeného subjektu a konkrétní situace“.$^{70} \mathrm{~K}$ tomu Ústavní soud uvedl, že ,[ani] ústavodárce nesmí prohlásit za ústavní zákon normu, která charakter zákona, natož ústavního, postrádá. Opačný postup je protiústavní svévolí."71

Chybou zákonodárce nebylo přijetí zákona, který by bezdůvodně omezoval některá práva či sledoval závadný účel. Chyba spočívala v tom, že zákonodárce pojmenoval určitý text ústavním zákonem a zasadil ho do hierarchie právního řádu, ačkoliv tento text svou povahou zákonem vůbec nebyl. Pokud zákonodárce svévolně vytvoří text, který nenaplňuje požadavky obecnosti ${ }^{72}$ nebo normativnosti, ${ }^{73}$ pak taková svévole je svévolí typu formálního, nikoliv technického. Technickou svévolí je totiž vytvoření zákona, který - ač je špatně uspořádán - je stále zákonem. Naproti tomu text, který postrádá všeobecnost nebo normativnost, zákonem není a svévole zde nespočívá ve vadě v textu, ale v prohlášení tohoto textu za zákon.

65 Ústavní zákon č. 195/2009 Sb., o zkrácení pátého volebního období Poslanecké sněmovny.

66 MOLEK, P. „Hluboce inspirující“ nález Pl. ÚS 27/09 a utržené ucho materiálního jádra Ústavy. In: Soudní rozhledy [online] 2009, č. 10. Dostupné na Beck-online [právní informační systém] C. H. Beck [cit. 17. 10. 2015].

67 Ústavní zákon č. 195/2009 Sb., o zkrácení pátého volebního období Poslanecké sněmovny.

68 Zákon byl následně Ústavním soudem shledán neústavním. Ústavní soud se v nálezu vyjádřil, že přijetím takového zákona došlo k obcházení demokratických principů právního státu. Nález Ústavního soudu ze dne 10. 9. 2009, sp. zn. Pl. ÚS 27/09.

$69 \mathrm{Z}$ důvodu dělby moci nelze, aby o konkrétních př́ípadech rozhodoval zákonodárce. SMEJKALOVÁ, T. Právní věty a ratio decidendi. Jurisprudence, 2012, č. 5, s. 3.

70 Nález Ústavního soudu ze dne 10. 9. 2009, sp. zn. P1. ÚS 27/09.

71 Tamtéž.

72 Obecnost norem je podstatnou náležitostí demokratického právního státu. KÜHN, Z. Nad nálezem Ústavního soudu ve věci protiústavního „ústavního“ zákona č. 195/2009 Sb. Právní rozhledy, 2010, č. 1, s. 27.

73 TOMŠEJ, J. „Porcování medvěda“: protiústavní deformace řádné legislativní procedury? Právní rozhledy, 2009 , č. 19 , s. 705 . 


\section{ZÁVĚR}

Když Ústavní soud uživá pojem svévole zákonodárce, pak ho naplňuje (at' už vědomě, či nevědomě) určitým obsahem. Obsah je dán právě způsobem užití pojmu. Vnímání pojmu svévole zákonodárce je ale značně subjektivní, a protože ho kromě Ústavního soudu používají i jiné osoby, může být každou z těchto osob chápán odlišně a naplňován odlišným obsahem. Nicméně na rozdíl od všech ostatních osob, je právě Ústavní soud tím, jehož výroky mají právní následky pro zákonodárce a objektivní faktický dopad na podobu práva. ${ }^{74} \mathrm{Z}$ toho důvodu je právě analýza způsobu používání jazyka Ústavním soudem užitečná. Co tedy lze odvodit z nálezů Ústavního soudu o pojmu svévole zákonodárce?

Ústavní soud v některých nálezech, jimiž zrušil zákony pro neústavnost, označil zároveň zákonodárce za svévolného, přičemž právě na svévoli zákonodárce poukázal jako na důvod neústavnosti právního aktu. Ve většině př́padů Ústavní soud obecně nevymezuje, jaká zákonodárcova jednání považuje za svévolná. $Z$ jednotlivých nálezů se tak lze především dozvědět, co bylo svévolí v tom kterém konkrétním prŕípadě. Pouze v několika málo nálezech pak Ústavní soud nabízí zobecnění svých úvah o svévoli a explicitně označuje svévolným jednáním zákonodárce přijetí takové právní úpravy, která (a) nemá racionální vazbu na svůj účel nebo (b) není schopna svého účelu dosáhnout. Ukázalo se, že toto explicitní vymezení nelze chápat jako vyčerpávající definici toho, co podle rétoriky Ústavního soudu svévolí zákonodárce je. Svévole tak není jednolitým pojmem zahrnutelným pod podobně jednoduchou definici, nýbrž vnitřně diferencovaným konceptem. Jako takový vyžaduje, aby k němu bylo přistupováno jako $\mathrm{k}$ souboru různých jevů, které je třeba nejdř́ve prozkoumat samostatně. Vytvořila jsem proto typologii svévole zákonodárce. Musela jsem ovšem nalézt společné kritérium pro vymezení jednotlivých typů. Kritériem svévole se tak stalo rozdělení chyb zákonodárce, jež Ústavní soud shledává neústavními. Právě od něho jsem odvodila čtyři typy svévole - materiální, formální, technickou a procedurální. Následky každého z typů svévole vykazují charakteristické rysy, které je odlišují od typů ostatních. Explicitní vymezení svévole přitom dopadá bez dalšího právě jen na př́ípady materiálního typu svévole zákonodárce, zbývajícím třem typům se takového explicitního vyjádření v rámci judikatury Ústavního soudu nedostalo. Jestliže se ale zákonodárce dopustí svévole, pak tím nemusí nutně vytvořit neústavní právní akt. Minimálně v př́ípadech úpravy sociálních práv, při jejichž přezkumu ústavnosti je aplikován test rozumnosti, rozlišuje Ústavní soud intenzitu svévolného jednání zákonodárce. Jen ty právní akty, při jejichž přijímání se zákonodárce nedopustil svévole „flagrantní“, shledá Ústavní soud jako neústavní, ostatní zásadně považuje za ústavně konformní. Avšak ani v jiných př́ípadech, kdy není aplikován právě test racionality, nemusí být neústavnost právního aktu automatickým následkem svévole zákonodárce. Svévole zákonodárce je sice prŕíčinou neústavnosti právního aktu, nicméně ta může vznikat až později přistoupením dalších okolností, v je-

${ }^{74}$ Zrušení právního předpisu je ústavněprávní sankcí zákonodárci (FILIP, J. Ústavní právo České republiky. Brno: Václav Klemm, 2011, s. 47); v souladu s § 82 odst. 3 písm. b) zákona č. 182/1993 Sb., o Ústavním soudu, ve znění pozdějších předpisů může Ústavní soud zakázat zákonodárci pokračovat v porušování zákona, jestliže zákonodárce jedná neústavně. 
jichž důsledku se negativní dopady zákonodárcovy svévole projeví jako intenzivnější. Zda tedy bude svévolně príjatý právní akt shledán Ústavním soudem jako neústavní, může záviset (a) jak v intenzitě svévole zákonodárce, tak i (b) v intenzitě následků, které svévolně príijatý právní akt vyvolává.

Hledat odpovědi na takové otázky po významu pojmů není podstatné pouze s ohledem na zájmy akademicko-teoretické. Jde totiž o problematiku úzce blízce související s praxí. Jestliže je zrušení neústavního právního ustanovení ústavněprávní sankcí, ${ }^{75}$ můžeme se ptát, zda by taková sankce měla zahrnovat i odpovědnost zákonodárce (potažmo státu) k náhradě legislativní újmy. Pokud by totiž takovou odpovědnost sankce obsahovala, museli bychom načrtnout hranice povinnosti k náhradě. Neboli určit ty př́pady, kdy by legislativní újma byla nahrazována. A právě $\mathrm{k}$ tomu může být prospěšné definovat pojmy, které už jsou v jazyce př́tomny, mají svůj obsah a mohou být využity při konstrukci teorie či pojmosloví problematiky legislativní újmy.

Mgr. Bc. Jana Kokešová

Katedra právní teorie, Právnická fakulta Masarykovy univerzity v Brně jana.kokesova@post.cz

75 FILIP, 2011, c. d., s. 47. 